\title{
PRODUCTION OF CELLULASE-FREE XYLANASE BY TRICHODERMA REESEI SAF3
}

\author{
Sanjay Kar; Asish Mandal; Pradeep K. das Mohapatra; Keshab C. Mondal; Bikash R. Pati* \\ Department of Microbiology, Vidyasagar University, Midnapore, India
}

Submitted: October 12, 2005; Returned to authors for corrections: March 03, 2006; Approved: July 18, 2006

\section{SHORT COMMUNICATION}

\begin{abstract}
Axylanase producing fungi has been isolated from soil and identified as Trichoderma reesei SAF3. Maximum growth of the organism was found at $48 \mathrm{~h}$ under submerged condition in xylan containing enriched medium, whereas highest enzyme production $(4.75 \mathrm{U} / \mathrm{mL})$ was recorded at $72 \mathrm{~h}$. No detectable cellulase activity was noted during whole cultivation period. The partially purified enzyme hydrolyzed xylan into xylopentose and xylose. All these properties of xylanase highlighten its promising uses in industrial scale.
\end{abstract}

Key words: xylanase, Trichoderma reesei, submerged fermentation

\section{INTRODUCTION}

Xylanase is responsible for hydrolysis of xylan, a major hemicellulose of plant cell wall (second most abundant). This enzyme is extensively used in food processing, chemical and pulp industries (7). The major uses of this enzyme are biopulping, biobleaching, clarifying and liquefying fruit and vegetables juices. In paper and pulp industries use of xylanase causes decrease in consumption of chlorine, absorbable organic halogen (AOX), chemical oxygen demand (COD) and improves thereby the quality of wastewater.

Although xylanases from eubacteria and archaebacteria have considerable higher temperature optima and stability than those of fungi, but the amount of enzyme produced by these bacteria is comparatively lower than that produced by fungi. In general, the level of xylanase in fungal culture is typically much higher than those from yeasts or bacteria (8). A filamentous fungus, particularly Trichoderma sp. Is useful producer of xylanases from the industrial point of view. The reasons are many fold they are non pathogenic, capable of producing high levels of extra cellular enzymes and they can be cultivated very easily. In this present study Trichoderma sp has been isolated from soil sample and its xylanase production ability has been examined. Some characteristics of the partially purified xylanase have also been evaluated.

A number of xylanase producing microorganisms were isolated from different soils of District Paschim Medinipur, West Bengal, India, on selective xylan-agar medium by plate dilution technique. The composition of isolating media was $(\mathrm{g} / \mathrm{L}) \mathrm{K}_{2} \mathrm{HPO}_{4}$ 2.0; $\mathrm{KH}_{2} \mathrm{PO}_{4} 2.0 ; \mathrm{NH}_{4} \mathrm{NO}_{3} 2.0 ; \mathrm{MgSO}_{4} 0.6 ; \mathrm{CaCl}_{2}$ 0.5; birch wood xylan 10.0, Agar 20.0. Before sterilization, xylan was completely dissolved in water by sonication $(10 \mathrm{hz}, 3 \mathrm{~min})$. Xylanase producers have been screened on the basis of formation of larger clear zone around them in xylan-agar plate and they are preserved in PDA slant at $4^{\circ} \mathrm{C}$.

Identification of the best xylanase producing fungal strain was made on the basis of morphological, cultural and reproductive characteristics followed by the method of Larone (5) and St. Germain (9). Identification was also confirmed from Microbial Type Culture Collection Centre (Chandigarh, India) and the collection no. is MTCC-4876.

Enzyme production by the selected fungus was carried out in $250 \mathrm{~mL}$ Erlenmeyer flasks containing $50 \mathrm{~mL}$ of isolating medium (devoid of agar). Fresh fungal spores have been used as inoculums and $0.5 \mathrm{~mL}$ spore suspension (containing around $2.5 \times 10^{4}$ spores $/ \mathrm{mL}$ ) was added to the sterilized medium and

*Corresponding Author. Mailing address: Department of Microbiology, Vidyasagar University, Midnapore, 721102, West Bengal, India. Fax: (+91) 3222 275329. E-mail: brpati@yahoo.com 
cultivated at $30^{\circ} \mathrm{C}$ for $72 \mathrm{~h}$ in a rotary shaker $(200 \mathrm{rpm})$. The clear supernatant of the culture was assayed for enzyme activity, which was obtained by centrifugation $(5000 \times \mathrm{g}$ for 10 min) and followed by filtration (Whatman no. 1 paper). The growth of the fungus was estimated on the basis of biomass dry weight $(\mathrm{mg} / \mathrm{mL})$.

The partially purified xylanase was obtained by ammonium sulphate (60-80\% saturation) precipitation followed by DEAE cellulose column chromatography. The active enzyme fractions were concentrated by freeze-drying and this was used for the study of the enzyme properties.

Xylanase and cellulase activity were assayed by measuring released reducing sugars from birch wood xylan (Fluka) and carboxy methyl cellulose (Sigma, USA) respectively with 3,5dinitrosalicylic acid (6). The reaction mixture containing $0.2 \mathrm{M}$, pH 5.0 acetate buffer, $0.3 \mathrm{~mL}$ of $1 \%(\mathrm{w} / \mathrm{v})$ xylan and $0.3 \mathrm{~mL}$ enzyme solution was added to a final reaction volume of $1 \mathrm{~mL}$. In case of cellulase activity, $0.5 \mathrm{~mL}$ of $1 \%(\mathrm{w} / \mathrm{v})$ carboxy methyl cellulose was added to a final reaction volume of $1 \mathrm{~mL}$. The enzyme reactions were carried out at $50^{\circ}$ and $40^{\circ} \mathrm{C}$ respectively and after $30 \mathrm{~min} 1 \mathrm{~mL}$ of DNS $(3 \% \mathrm{w} / \mathrm{v})$ was added to stop the reactions. The solution was incubated in a boiling water bath for $15 \mathrm{~min}$ for colour development and the absorbency was measured at $540 \mathrm{~nm}$ against the enzyme blank. One unit of xylanase/ cellulase is defined as the amount of enzyme required to release $1 \mathrm{mmol}$ reducing sugar as xylose /glucose equivalent per min under the above assay conditions.

The hydrolysis products of xylan by the action of xylanase were identified by paper chromatography. Initially xylan solution was incubated with partial purified xylanase (concentrations and amounts remain same as the assay condition) and $50 \mu \mathrm{L}$ sample was taken at different time intervals and spotted on paper (Whatman $1 \mathrm{~mm}$ ). Chromatography was done by using $\mathrm{n}$ butanol, acetic acid and water as a carrier solvent system in a ratio of 4:1:5. The carbohydrate residues in paper were stained by silver nitrate.

A potent xylanase producing fungi was isolated from soil and according to morphological and reproductive characteristics it was identified as Trichoderma reesei SAF3.

The time course of xylanase production in relation to growth of $T$. reesei SAF3 is illustrated in Fig. 1. Under the fermentation condition, fungal biomass increased up to $48 \mathrm{~h}$, after that there was a decline in its amount. Extra-cellular xylanase production exhibited a similar increase following the biomass peak; remain in higher amount $(4.75 \mathrm{U} / \mathrm{mL})$ in medium up to $72 \mathrm{~h}$, probably as a result of autolytic release of the enzyme (1). The fungus did not show cellulase activity (Fig. 1) when grown in liquid medium containing xylan as inducer, suggesting that the production of cellulolytic and xylanolytic enzymes is under separate regulators control (3).

The periodic hydrolysis of xylan by the partially purified xylanase of the present isolate has been studied and represented

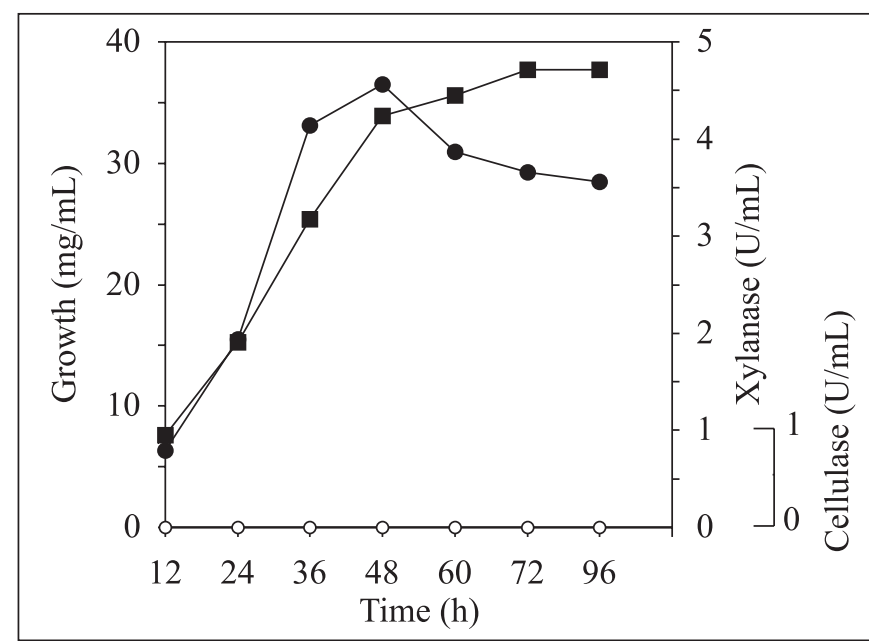

Figure 1. Time course of xylanase production $(\mathbf{O})$, cellulase production (O) and growth ( $\square$ ) of Trichoderma reesei SAF3. Submerged fermentation was carried out at $30^{\circ} \mathrm{C}$ with initial medium $\mathrm{pH}$ of $5.0 \mathrm{in}$ a rotary shaker $(200 \mathrm{rpm})$.

in Fig-2. From the initial period of hydrolysis, only two specific products are produced, one is xylose and the other is xylopentose (detected in respect to $R f$ value). Gradually the xylopentose is hydrolyzed into xylose by the action of the enzyme within $120 \mathrm{~min}$ of reaction. This result reveals that this enzyme system comprises of two sets of enzymes (2) namely endo-1-4$\beta$-xylanase (EC 3.2.1.8) and $\beta$-xylosidase (EC 3.2.1.37). The former enzyme specifically hydrolyzes xylan to xylopentose and the latter produces xylose from xylopentose. The endoxylanase activity of this enzyme is quite unlike as it produces only pentamer sub-fragments. Chen et al. (4) characterizes an endo-

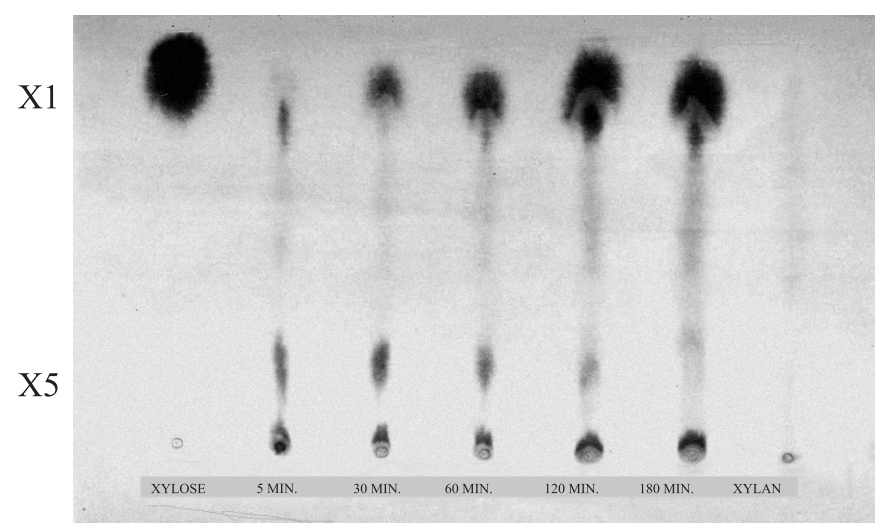

Figure 2. Paper chromatographic analysis of periodic xylan degradation by partially purified xylanase from Trichoderma reese $\mathrm{SAF} 3$. The symbol $\mathrm{X} 1$ indicated the production of $x y$ lose and X5 indicated xylopentose. 
xylanase from T. longibrachiatum, which produces a mixture of xylobiose, xylotriose, xylotetrose and higher oligosaccharides after $23 \mathrm{~h}$ of hydrolysis.

The present study reveals that this xylanase is very much promising as because it is produced in large amount from the indigenous mesophilic fungus $T$. reesei SAF3, moreover, it is salt tolerant (stable at $2 \mathrm{M} \mathrm{NaCl}$ ) and stable in broad range of $\mathrm{pH}$ (3-7)[data not included]. All these characteristics of xylanase of the newly isolated Trichoderma reesei SAF3 showed its uniqueness from the other strains of Trichoderma.

\section{ACKNOWLEDGEMENTS}

Authors are gratefully acknowledged to the Hon'ble Vicechancellor of Vidyasagar University for financial assistance for this project work.

\section{RESUMO}

\section{Produção de xilanase livre de celulase por Trichoderma reesei SAF3}

A partir de solo, isolou-se uma cepa de fungos produtos de xilanase, posteriormente identificado como Trichoderma reesei SAF3. O crescimento máximo do fungo foi obtido após $48 \mathrm{~h}$ em condições submersas em meio de cultura contendo xilano, enquanto produção máxima de enzima $(4,75 \mathrm{U} / \mathrm{mL})$ ocorreu em 72h. Durante o período de cultivo, não foi detectada atividade celulásica. A enzima parcialmente purificada hidrolizou xilano a xilopentose e xilose. Essas propriedades da xilanase destacam seu uso promissor em escala industrial.

Palavras-chave: xilanase, Trichoderma reesei, fermentação submersa

\section{REFERENCES}

1. Bajpai, P. Microbial xylanolytic enzyme system: Properties and application. Adv. Appl. Microbiol., 43, 141-194, 1997.

2. Biely, P. Microbial xylanolytic system. Trends Biotechnol., 3, 286290, 1985.

3. Biely, P. Biochemical aspects of the production of microbial hemicellulases. In: Coughlam, M.P.; Hazlewood, G.P. (eds.). Hemicellulose and hemicellulases. Potland press, London, 1993, p.127-143.

4. Chen, J.L. Studies on the production, purification and characterization of a xylanase from Trichoderma sp. 1995, 185p. (M.S.Thesis, National Chung-Hsing University, Taiwan).

5. Larone, D.H. Medically important Fungi: A Guide to Identification, $3^{\text {rd }}$ ed. ASM, press, Washington, D.C., 1995.

6. Miller, G.L. Use of dinitroasalisilic acid reagent for determination of reducing sugar. Anal. Chem., 31, 246-248, 1959.

7. Seyis, I.; Aksoz, N. Investigation of factors affecting xylanase activity from Trichoderma harzianum 1073 D3. Brazilian Archives Biol. Technol., 48, 187-193, 2005.

8. Singh, S.; Pillay, B.; Prior, B.A. Thermal stability of $\beta$ xylanases produced by different Thermomyces lanuginosus strains. Enzyme Microb. Technol., 26, 502-508, 2003.

9. St. Germain Summerbell, G.R. Identifying Filamentous Fungi: A clinical Laboratory handbook. $1^{\text {st }}$ ed. Star Publishing Company, Belmont, California, 1996. 